\title{
Opiekunki i pielęgniarki w wybranych utworach Stefana Żeromskiego
}

Ko obieta pochylająca się nad rannym, chorym lub umierającym mężczyzną ${ }^{1}$. Tak w skrócie można scharakteryzować scenę pojawiającą się w kilku powieściach Stefana Żeromskiego, między innymi w Promieniu, Dziejach grzechu, Wiernej rzece. Mężczyzna nie zostaje „pacjentem” przypadkowo; bywa raniony w boju, w pojedynku, uczestniczy w ważnych „dla sprawy” wydarzeniach, jest społecznikiem, lekarzem. W momentach fizycznego kryzysu staje się całkowicie zależny od kobiety, pozbawiony możliwości wyboru i tego, co jest akurat dla niego istotne - działania. Rezultat ich spotkania jest wyłącznie binarny; kończy się śmiercią chorego albo stosunkiem erotycznym z opiekunką ${ }^{2}$. Pacjent angażuje się w miłość, gdyż, jak pisze Agata Zalewska, osoby uczestniczące w opisanej sytuacji zostają doświadczone „niebywałym wręcz - pięknem, silnym uczuciem zauroczenia i miłości, ale również zmysłowością, temperamentem, erotyzmem (uświadomionym bardziej lub mniej), siłą cielesności i seksualności"3.Opieka nad chorym sprawia, iż gra rozpoczyna się na innym poziomie - znika świat i jego problemy. Ofiara choroby, pojedynków, działań powstańczych, zaczyna

\footnotetext{
* Dr hab. Marek Kochanowski, Prof. UwB - Zakład Literatury Pozytywizmu i Młodej Polski w Instytucie Filologii Polskiej Wydziału Nauk Humanistycznych Uniwersytetu w Białymstoku; e-mail: mkochanowski@poczta.onet.pl.

${ }^{1}$ Por. hasła Opiekunka, Pielegniarka, Chory, Pacjent w: K. Handke, R. Handke, Świat kobiet i świat mężczyzn. Słownictwo Pism Stefana Żeromskiego, t. XIII, Kraków 2007.

$2 \mathrm{~W}$ polskim literaturoznawstwie istnieje niewiele rozpraw poświęconych figurze pielęgniarki. Najobszerniejszym studium jest praca Zygmunta Pucki:Wybrane motywy pielegniarki w literaturze. Szkice filozoficzne (Kraków 2016), poświęcona głównie obrazom pielęgniarki w prozie Ondaatjego, Irvinga, Sołżenicyna, Coetzeego, Kesey’a. W książce tej na uwagę zasługuje zwłaszcza streszczenie motywów pielęgniarki w badaniach anglosaskich.

3 A. Zalewska, Legenda i lektura. O „Dziejach grzechu” Stefana Żeromskiego, Warszawa 2016, s. 109. Por także: J. Zacharska, Kobieta, wina i grzech w utworach Żeromskiego, [w:]Klucze do Żeromskiego, red. K. Stępnik, Lublin 2003.
} 
fascynować się opiekunką, a rozwijająca się psychodrama, często związana ze sferą erotyczną, pokazuje bezwolność mężczyzny podporządkowanego kobiecie. Przyjrzyjmy się, jak w wybranych utworach Żeromskiego wygląda relacja między opiekunką/pielęgniarką ${ }^{4}$ a mężczyzną z różnych powodów skazanym na jej towarzystwo. W celu zilustrowania tej relacji wybrałem trzy wymienione powyżej utwory autora Przedwiośnia. I chociaż różnią się one zawartą w nich problematyką, to wszystkie zawierają pewne cechy wspólne występujące w obrazowaniu kobiecych bohaterek.

\section{Dzieje grzechu. Miłość jako walka}

Dzieje grzechu $u^{5}(1908)$ to powieść, która w ostatnich latach cieszy się dużym zainteresowaniem literaturoznawców ${ }^{6}$. W I tomie utworu Ewa Pobratyńska, jedzie do Zgliszcz ${ }^{7}$, aby odwiedzić w szpitalu i otoczyć opieką Łukasza Niepołomskiego. Zgliszcza, jak wskazuje symboliczna nazwa, to miejsce opuszczone, wymagające odbudowy. A Ewa jest osobą próbującą świat uporządkować, jej altruistyczny charakter ujawnia się już w początkowej drodze z kościoła, gdy oddaje żebrakowi wszystkie posiadane przez siebie pieniądze.

${ }^{4}$ O kobietach w twórczości Żeromskiego czyt. m.in. w: W. Gacki, Kobiety i miłość w twórczości St. Żeromskiego, Warszawa 1936; A. Hutnikiewicz, Imiona miłości, [w:], Żeromski, Warszawa 2000, s. $278-302$

${ }^{5} \mathrm{Na}$ temat recepcji wszystkich omawianych powieści czyt. w: S. Eile, S. Kasztelowicz S Stefan Żeromski. Kalendarz życia i twórczości, Kraków 1976. Streszczenie głosów krytyków omawiających postać Ewy Pobratyńskiej oraz innych bohaterów Dziejów grzechu przedstawił D. Trześniowski w artykule Kim jest Ewa Pobratyńska. Rzecz o antypsychologizmie Żeromskiego, [w:] Światy Stefana Żeromskiego: studia,red. M.J. Olszewska, G.P. Bąbiak, Warszawa 2005, s. 423-426. Trześniowski traktuje Ewę jako projekcję męskich wyobrażeń, „niesamodzielny byt, dopasowujący się do ról, oferowanych przez męski świat”, dz. cyt. s. 429. Por. także: M. Głowiński, Konstrukcja a recepcja (Wokót „Dziejów grzechu”), [w:] Tegoż, Gry powieściowe, Warszawa 1973; A. Wrońska, Elementy paraboli w „Dziejach grzechu” Stefana Żeromskiego, „Kieleckie Studia Filologiczne” 1997, t. 11; W. Gutowski, Stefan Żeromski - „Dzieje grzechu”, [w:] Lektury polonistyczne. Od realizmu do preekspresjonizmu, red. G. Matuszek, Kraków 2001; J. Zacharska J., Kobieta, wina i grzech w utworach Żeromskiego, w: Klucze do Żeromskiego, dz, cyt.

${ }^{6}$ Por. chociażby: A. Gogolin, Miłość w twórczości Stefana Żeromskiego, „Akant” 2006, nr 12; M. Kochanowski, Melodramatyzm i powieść (Żeromski, Mniszkówna, Strug). Od rytuału do sensacji, Białystok 2015; A. Zalewska, Legenda i lektura. O „Dziejach grzechu” Stefana Żeromskiego, Warszawa 2016. Zob. także poświęcony w całości powieści kwartalnik „LiteRacje” 2011, nr 2. Najnowsze omówienie recepcji powieści zawiera przywołana książka Zalewskiej.

7 Pamiętajmy, iż w jakiś sposób dzieło Żeromskiego można interpretować jako odpowiedź na rewolucję 1905 r. Por. A. Grzymała-Siedlecki, Dobra wieść o złym, „Tygodnik Ilustrowany” 1912, nr 19; H. Markiewicz, Stefan Żeromski wobec rewolucji, „Pamiętnik Literacki” 1951, z. 1. Jak pisał A. Hutnikiewicz: „Katastrofalny bieg wydarzeń wpływał na nastrój piszącego, a ten z kolei udzielał się samemu dziełu", tegoż, Żeromski, Warszawa 2000, s. 107. 
Początkowo Łukasz przebywa w szpitalu, o którym w Dziejach grzechu pisze się negatywnie, jako o „państwie przepotężnym, urągającym wszystkim mocom

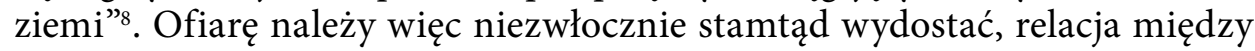
kochankami nie może być podtrzymana w nieludzkich warunkach. I chociaż protagonistom nie jest dana samotność, to już pierwsza scena ich spotkania zdradza poświęcenie bohaterki: „Przyklękła obok łóżka jakby na rozkaz. Rozpalona ręka spoczęła w jej włosach. Oczy toną we łzach i nic nie widzą. W jego oczach szerokich, ognistych - szczęście bez granic. Głos suchy, trudny, oddech chwytany." (DG I 157).Wiemy oczywiście, iż między kochankami jest miłość, narodziła się ona znacznie wcześniej, intymna sytuacja choroby sprawiła, iż nastąpił rozwój doznań zmysłowych: „Codziennie była przy łóżku chorego, opiekowała się nim, czytała mu, grała z nim w szachy [...]” (DG I 160).

Po wypisaniu z szpitala opieka Pobratyńskiej nad Łukaszem staje się intensywniejsza, aczkolwiek ich warunki bytowe ulegają pogorszeniu. Znaczący jest zwłaszcza kontrast świata zewnętrznego $\mathrm{z}$ opisem poświęcenia się bohaterki: „Wieczny smród z owego dołu między kamienicami, z nigdy niewywożonych odchodów, brudy śmietnika odtajałe spod śniegu.” (DG I 162).Czas miłości, kuracja poza szpitalem, wprowadza perspektywę symboliczną, codziennym rytuałom towarzyszy doznanie mistycznie rozumianej miłości: „Nareszcie wejście na schody. Okienko i tam. Z wysoka pada brzask mistyczny, skądś z nieprzemożonego mroku" (DG 162). Mistyczny brzask symbolizuje miłosny idealizm i alienację postaci, narrator wielokrotnie podkreśla wyobcowanie bohaterów: „Ta okoliczność, że mieszkanie Łukasza oraz pokoik Ewy znajdowały się w dzielnicy zamieszkanej przeważnie przez Żydów, że znajdowały się za miastem, niejako poza obrębem kultury i dobrych obyczajów.” (DG I 164). Jest to przestrzeń „oczyszczona” z zasad i przyzwyczajeń świata zewnętrznego, miejsce inicjacji rodzącej się niejako na przekór religii (Łukasz cały czas jest formalnie w związku małżeńskim).

W czasie jej opieki nad Niepołomskim role się odwracają. Do tej pory to młody filozof był mentorem Pobratyńskiej, jej duchowym opiekunem, teraz Ewa $^{9}$ staje się osobą, od której zależy dalszy los kochanka. Łukasz, osłabiony

${ }^{8}$ Z. Żeromski, Dzieje grzechu, t. I. Korzystam z edycji opublikowanej w Pismach Zebranych (t.12-13) pod red. Z. Golińskiego, Warszawa 2015, s. 155. Dalej w tekście stosuję skrót DG z numerem tomu i strony w nawiasie. W przypadku Promienia i Wiernej rzeki korzystam z edycji wydanych w ramach: S. Żeromski, Dzieła, red. S. Pigoń, Warszawa 1955-1973: Promień (t.2) - P; Wierna rzeka (t. 10) - WR.

${ }_{9}$ Ciekawą analizę postaci Pobratyńskiej przedstawiła A. Zdanowicz w książce Metafizyka i życie społeczne. Stefan Żeromski wobec problemów współczesności, Warszawa 2005. Zdanowicz grupuje wszystkie możliwe interpretacje postępowań bohaterki w trzy szeregi znaczeniowe, w których Ewa jest kolejno: bohaterką powieści naturalistycznej i obyczajowej, projekcją modernistycznej kultury oraz medium zbiorowej podświadomości. Pierwszy model badaczka wiąże z programem etycznym Edwarda Abramowskiego, rozumianym jako „wyzwolenie wewnętrznych głosów i pragnień 
fizyczną porażką w pojedynku ze Szczerbicem, staje się uzależniony od swojej opiekunki oraz skazany na długotrwałe dni rekonwalescencji w łóżku. Wraz z porami roku i następstwem poszczególnych miesięcy, zaczyna się jego powrót do zdrowia: „W końcu stycznia Niepołomski począł siadać - wkrótce podnosić się, chodzić po pokoju. W połowie lutego w ciepłe dni wychylać się począł na dwór." (DG I 166). Wiosna to mityczny czas inicjacji, regeneracji, działania ekstatycznego. Powieść zaczyna się wiosną, bohaterkę poznajemy w czasie jej powrotu do domu $\mathrm{z}$ kościoła $\mathrm{w}$ chwili zimowego przesilenia, symbolicznych, cyklicznych narodzin. Łukasz zaczyna odzyskiwać siły po pojedynku ze Szczerbicem właśnie na wiosnę. Lecz choć wraz z rekonwalescencją wzmaga się uczucie bohatera, to walce $\mathrm{z}$ chorobą często towarzyszy walka $\mathrm{z}$ miłością: „Ramiona podnosiły się i pięści zaciskały jak do bitwy, żeby się siec w pałasze ze sobą samym, żeby zdusić namiętne marzenia." (DG I 166).

Bój ze wzrastającym pożądaniem przypomina batalię: „Był ponad siły, nad możność zniesienia, stan obcowania $\mathrm{z}$ nią, uwielbienia jej, dotykania jej rąk, małych dłoni, które były tkliwe i wymowne jak żyjące istoty." (DG I 166). Pierwsze opisy ich rodzącej się miłości zawierają elementy związane z witalnością ${ }^{10}$ : „Był ponad siły stan spoczywania oczyma w jej oczach, co opromieniały wszystko jak słońce[...]" (DG I 166) ${ }^{11}$. Walka bohatera z pokusami nabiera charakteru nadludzkiego: „Po tytanicznych porywach, po wysiłkach duszy $\mathrm{w}$ istocie potężnych, po przyrzeczeniach $\mathrm{w} k \mathfrak{\mathrm { k }} \mathrm{b}$ zmotanych - nastawały chwile ciszy." (DG I 167). Opisy rozwijającej się miłości zaczynają przypominać pole bitewne. Mężczyzna walczy nie tylko z chorobą, ale również z własną pożądliwością, choroba staje się tu tylko zasłoną dla innych odczuć: „Kiedy zbliżała się godzina jej nadejścia, pokój stawał się ciasny i mały niby klatka. Piersi były za małe dla mnóstwa zamkniętych westchnień, nagłych szlochań i bezimiennych wybuchów. Łukasz tłukł się w izbie od ściany do ściany, od drzwi do okna, od okna do drzwi." (DG I 168).

W Dziejach grzechu miłość nie tylko przypomina spotkanie bitewnych żywiołów, co i agonalne poświęcenie: „Gdyby Łukasz zażądał ofiary z ciała i duszy, nie zawaha się ani chwili” (DG I 170). Ewa odczuwa „litość nad jego cielesnym pragnieniem" (DG I 171), ale jednocześnie erotyka w jej rozmyślaniach

jako warunku samorealizacji i prawdziwej wolności” i oswobodzenie się spod jarzma katechizmu. Tamże, s. 144.

${ }^{10}$ Więcej na temat młodopolskiego witalizmu czytaj w: Młodopolski witalizm. Modernistyczne witalizmy, red. A. Czabanowska-Wróbel, U.M. Pilch, Kraków 2016.Tam zwłaszcza teksty A. Czabanowskiej-Wróbel, M. Popiel, W. Gutowskiego.

${ }^{11}$ W. Gutowski analizuje epizod związany z rekonwalescencją Łukasza w Dziejach grzechu w kontekście miłości absolutnej (zmysłowo-metafizycznej) i zauważa, iż Pobratyńska ucieka z domu, by „zamieszkać w syntezie miłosnych mitów”. Postacie dostępują wtedy erotycznego wtajemniczenia, w czasie którego „znikają granice między Ja i Ty, zmysłowym i duchowym”. Por, tegoż, Nagie dusze i maski. O młodopolskich mitach miłości, Kraków 1997, s. 294. 
nabiera charakteru związanego $\mathrm{z}$ wolnością i wyzwoleniem z norm moralnych: „Nieraz, gdy siedziała $z$ dala, schylona nad książką, i miała oczy spuszczone, nieraz, gdy sądził, że jest do gruntu zajęta pracą gospodarską, przeszywała ją wszechogarniająca myśl nagła, ślepa ekstaza, żeby go uszczęśliwić... Nie mówiąc słowa, zdjąć suknie...” (DG I 171) ${ }^{12}$. I jeszcze jeden cytat: „Ewa od dawna spostrzegła, co się dzieje." (DG I 169).

W czasie miłosnej psychodramy zaczynają się aktywizować różne strategie, wymieńmy kilka:

- odrzucenie i obrażenie: „Gdy oczy podniosła, leżał półodwrócony do ściany, ze zmarszczonymi brwiami i zagryzioną wargą." (DG I 171) - zagryziona warga oznacza niekontrolowaną rozkosz i brak możliwości jej zaspokojenia,

- uznanie siły „przeciwnika”: „W tobie jest męstwo człowieka i siła człowieka. Ciebie mąż nie potrzebowałby zamykać w haremie, ani okrywać gałganami.” (DG I 176),

- batalizacja sytuacji intymnych na podobieństwo wielkiego starcia: „Ziemia dygotała. Chwiały się w oczach pagórki i mieniły niknące w nocy doliny.” (DG I 177),

- narodziny nowego, miłosnego ładu „Zbliżył się i spojrzał w oczy. Po raz pierwszy ujrzał nowe ich spojrzenie. Patrzyły spod górnych powiek daleko-daleko... Były zgasłe, przeraźliwe, bosko żyjące, a jakby umarłe." (DG I 178).

Dla porównania prześledźmy jeszcze późniejszą opiekę Ewy nad Jaśniachem. Znika wtedy język związany z obrazowaniem agonalnym, towarzyszący jej związkowi z Łukaszem. Pobratyńska będzie opiekować się poetą ,jak szarytka czy siostra" (DG II 16). Ewa zajmuje się Jaśniachem po bratersku:

Mówił wtedy, że się strasznie czegoś boi, a nie znajdując dla siebie miejsca, chciał co chwila zrywać się i uciekać. Musiała wówczas siedzieć przy nim na łóżku, opierać głowę na poduszce obok jego głowy, trzymać go za ręce i dać mu się wpół obejmować. Zmuszała go obecnością swego ciała do spokoju. Ta jej obecność i poświęcenie jakoś go zwyciężało. W Ewie zbudziło się wówczas miłosierdzie bez granic. (DG II 21).

Obecność Pobratyńskiej uspokaja poetę, bohaterka postanawia całkowicie poświęcić się jego pielęgnacji: „Ale nie była to miłość cielesna. Była to miłość umierającego dla anioła pocieszyciela, było to powitanie przez jego zmysły konające zjawiska innego świata (...)" (DG II 21).Jej działanie nie ma nic z seksualnego podtekstu: „Płaciła jego rachunki w hotelu i załatwiała wszelkie sprawy. Sprowadzała lekarzy i lekarstwa” (DG II 18). I chociaż Jaśniach pożąda swoją opiekunkę, to ona pełni wobec niego wyłącznie rolę pielęgniarki: „Ewa sama

${ }_{12}$ Więcej o przeżyciu doznania seksualnego przez Pobratyńską: A. Zalewska, dz. cyt., s. 375. 
wzięła na się z konieczności rolę lekarza. Zaczęła systematycznie zaznajamiać się z chorobami swego towarzysza." (DG II 19).

Miłosierdziu towarzyszącemu opiece Ewy nad Jaśniachem daleko jest do walki uczuć i emocji, towarzyszącej wcześniejszej relacji Pobratyńskiej i Łukasza. Ta sytuacja oraz następne jej kontakty z mężczyznami wywołane są potrzebą wykalkulowanego odwetu za los zostawionej kochanki. Chodzi wszak o to, aby „zdruzgotać w sobie Łukasza” (DG II 22). Projektowane, ale niezrealizowane oddanie choremu, jest więc w tym przypadku niczym więcej, jak formą rozprawienia się w wyobraźni z kochankiem: „A zemsta polegała na tym, żeby bezgraniczną łaską miłosierdzia otoczyć Jaśniacha i na tej drodze dojść do najwyższej, do najdalszej doskonałości” (DG II 22).

\section{Promień. Miłość i śmierć}

Marta Poziemska pojawia się w życiu Jana Raduskiego, głównego bohatera Promienia ${ }^{13}$, w sposób dość nieoczekiwany. W czasie burzy bohater widzi kobietę, próbującą schronić się pod konarami drzew. Ochrona przed deszczem staje się pretekstem do nawiązania znajomości, a jednocześnie towarzyszy napięciu erotycznemu w czasie ich pierwszego spotkania: „Jasnozielony stanik z wątłej, cieniutkiej materii przemókł zupełnie, przylgnął do ramion i piersi, pokazując szczegółowo nie tylko te miejsca, gdzie się urywał gorset, ale nadto haft szlaku koszuli. Spod sukni, którą trzymała w rękach, widać było złotawe buciki o wiśniowej cholewce, wyżej kostek w szarym błocie unurzane.” (P 78). Marta na co dzień opiekuje się swoim mężem Zygmuntem, byłym znajomym bohatera jeszcze z czasów studiów. Poziemski to lekarz, który wypełniając swoje zawodowe obowiązki zaraził się nosacizną. Ten szanowany kiedyś doktor ma świadomość, iż jego choroba wynika $z$ altruistycznego poświęcenia się innym, teraz więc tym bardziej odczuwa do wszystkich żal o to, że umiera osamotniony: „Buntuje się, przepełnia go gorycz, pogarda i wściekłość w stosunku do ludzi. To co go spotkało, odbiera jako szczególną niesprawiedliwość, życiową ironię"14.

Raduski odwiedza Poziemskich w ich mieszkaniu. W przestrzeni zdominowanej przez chorobę, zachowanie i wygląd Marty znacząco się zmieniają; ona ma „zaniedbany węzeł” we włosach, mówi „szeptem, zdaniami urywanymi,

${ }_{13}$ Badacze prozy Żeromskiego nie poświęcali jak do tej pory zbyt wiele miejsca Promieniowi. Do ciekawszych interpretacji należy tekst B. Obsulewicz, O idei miłosierdzia we wczesnej twórczości Stefana Żeromskiego, w: Światy Stefana Żeromskiego, red. M.J. Olszewska, G.P. Bąbiak, Warszawa 2005; A. Zdanowicz, W poszukiwaniu nowej „szkoły umierania” - o wczesnej twórczości Stefana Żeromskiego, w: Śmierć w literaturze i kulturze drugiej połowy XIX wieku, red. E. Paczoska, U. Kowalczuk, Warszawa 2002.

${ }^{14}$ A. Zdanowicz, dz. cyt., s.49-50. 
z wyrazem niepokoju" (P 83), ubrana jest w szarą, mało atrakcyjną suknię. Również otoczenie Poziemskiego wygląda przytłaczająco, a stan lekarza nie pozostawia złudzeń co do jego przyszłości: „Włosy miał krótkie, ucięte, zarost rzadki. Twarz jego była straszliwie wychudzona. Oczy czarne, zupełnie takie jak u córki, bez władzy leżały w głębi sinych dołów, okrążone szerokimi smugami." (P 83). Chory ma podkrążone powieki, zaostrzony nos i chude, białe przezroczyste dłonie, porównane do „martwych rękawiczek” (P 83).

Relacje między Poziemskimi oraz zachowanie bohaterki jest różne od sposobu w jaki komunikuje się ona $\mathrm{z}$ Raduskim. Wobec męża protagonistka jest apodyktyczna: „-Może byś nie rozmawiał, Zygmuncie? - rzekła do chorego pani Poziemska głosem takiego brzmienia, że Raduski w tej minucie coś w sobie jak gdyby złamał czy zmiażdżył." (P 84). Mąż również przenosi ból i zgorzknienie na jej osobę, lekarz w trakcie ataków choroby odnosi się wulgarnie do małżonki nazywając ją „suką”, „małpą” oraz wyzywając ją innymi słowami. Jego stosunek do niej przemieszany jest czułością, miłością, z pogardą i sadystyczną nienawiścią: „Płacimy za nie, stroimy je, oddajemy im cały zarobek, a gdy którego los zwali, to taka... wypoczywa." (P 91).

Opisywana relacja różni się od uczucia bohaterów z Dziejów grzechu. W Promieniu choroba działa destrukcyjnie na związek; w relacji Poziemskich dominuje znużenie żony i podenerwowanie męża. Szczegóły jego schorzenia opisywane są anatomicznie, w sposób naturalistyczny:

Chory spał dziwnym snem, więcej przypominającym śmiertelne wyczerpanie się samych cierpień niż szczęśliwe zapomnienie o nich. Strasznie blada i chuda twarz jego leżała na poduszce bez władzy jak głowa trupa, doły oczne czerniały niby jamy i tylko jęk wydzierający się z ust otwartych razem z oddechem świadczył, że w tym ciele życie jeszcze nie ustało. (P 89).

Codziennym zajęciem doktorowej jest przepłukiwanie nosa męża, zabieg ten opisywany jest mechanicznie. Chociaż narrator szczegółowo opisuje jej oddanie (Poziemska śpi przy łóżku swojego chorego męża na materacu), to widzimy, iż wszystkie czynności, jakie wykonuje, nabierają charakteru rutynowego i wyczerpującego: „Pani Marta wolno zbliżyła się do wezgłowia, uklękła przy nim i nagiąwszy rękoma ku poduszce głowę chorego zaczęła mu jak zwykle obcierać chustką oczy i skrzywione usta" (P 104), a sama bohaterka jest zmęczona wypełnianiem codziennych obowiązków: „Bardzo często w czynach jej, w dźwiękach głosu, w ruchach, w wyrazie twarzy, a szczególnie w tępych spojrzeniach widać było niemoc utrudzenia, wstręt i obojętność. Męstwo umysłu, wytrzymałość serca nie zmniejszały się w niej ani o jedną kreskę, ale ręce i nogi, uszy i oczy - ustały" (P 106).

Intymna sytuacja choroby i opieki pokazuje dojmujący przymus obowiązku, marazm i rutynę. Jednakże odebranie kobiecie roli pielęgniarki, którą bohaterka 
musi dzielnie znosić prowadzi do tragicznego końca: „Gdy wreszcie trumnę spuszczono na powrozach w głąb dołu, okropnie usiłowała rzucić się za nią, czemu adwokat Koszczycki z właściwą forsą przeszkodził" (P 108). Ten wymowny akt „podążania” za mężem pokazuje, iż życie Poziemskiej dobiegło końca wraz ze śmiercią chorego. Z czasem okaże się, iż uwikłanie bohaterki w sytuację opieki, jej przyjęcie roli pielęgniarki, doprowadzi ją do śmierci - zakażona nosacizną Marta wkrótce popełni samobójstwo.

\section{Wierna rzeka. Porażka opiekunki}

Wierna rzeka ${ }^{15}$ to fabularnie najspójniejszy utwór Stefana Żeromskiego z wyraźnie zarysowanym początkiem, ekspozycją $\mathrm{i}$ końcem. Rzeka ${ }^{16}$, woda ma w powieści charakter niejednoznaczny, metaforyczny i symboliczny ${ }^{17}$, przykładowo; $\mathrm{z}$ jednej strony uniemożliwi ucieczkę Hubertowi Olbromskiemu, przyjmie go i wchłonie w swoje odmęty, ale i wejście w jej bieg zamknie symboliczne koło jego żołnierskiej tułaczki.

Powieść zaczyna się od przerażającego opisu stosu martwych ciał po potyczce pod Małogoszczem w czasie Powstania Styczniowego oraz od obrazu zakrwawionego człowieka, który próbuje się z tego stosu oswobodzić. Ranny w prawe biodro powstaniec został tu, tak jak i inni, przywleczony przez wroga. Znaczące są już wstępne zdania charakteryzujące Odrowąża: „Głowa, zrąbana szablami w bitwie, wysączyła we włosy dużo krwi, która zastygła w zlepienia, w sople i utworzyła na czaszce istną czerwoną papkę." (WR 7). Bohater musi wydostać się na zewnątrz przez usypisko złożone $\mathrm{z}$ ciał jego poległych w walce towarzyszy. Czerwona papka na głowie symbolizuje ponowne narodziny, wychodzenie na świat, zapowiada inicjację, której bohater wkrótce z Salomeą dostąpi.

Pierwsze spotkanie z Brynicką przypomina doznanie mistyczne, przepojony cierpieniem powstaniec, dostrzega jej nieziemską urodę: „Wędrowiec podniósł na nią oczy i mimo ogrom swego nieszczęścia, poprzez półmgłę śmierci patrząc, zadziwił się i zachwycił jej pięknością." (WR 19). Między postaciami rozpoczyna

${ }^{15}$ Więcej o Wiernej rzece czyt. w: S. Eile, „Wierna rzeka” jako powieść historyczna, „Zeszyty Naukowe UJ” 1957, z. 3. W. Turek, O pierwszym wydaniu „Wiernej rzeki” Stefana Żeromskiego, „Pamiętnik Literacki” 2011, z. 1.

${ }_{16}$ Por. ciekawy artykuł M. Popiel, „Dokąd płynie ta woda, dokąd płynie?”, „Ruch Literacki” 1980 , $\mathrm{nr} 5$.

${ }^{17}$ Wielu badaczy podkreślało biegunowy charakter natury w twórczości Żeromskiego, która bywa „jednocześnie twórcza i niszcząca”, cyt. z M. J. Olszewska, Stefana Żeromskiego dar widzenia i przenikania świata, [w]: tejże, Stefan Żeromski. Spotkania, Warszawa 2015, s. 41. Por. także: A. Hutnikiewicz, Natura, [w]: tegoż, Żeromski, Warszawa 2000; K. Handke, Stosunek Stefana Żeromskiego do pejzaży: natury i miasta, w: Dworki - pejzaże - konie, red. K. Stępnik, Lublin 2002. 
się swoista gra ${ }^{18}$, bohaterka świadoma swojej przewagi, także fizycznej, zachowuje się wobec Odrowąża w sposób przywódczy i wyniosły, sama zaś narzuca na siebie rolę władczego lekarza:

- Dwór spalą...- rzekł do niej łagodnie, ociągając się po niewoli.

- Zobaczymy, jak to tam będzie, a teraz marsz, gdzie każą! - mruknęła z pośpiechem dźwigając go na schody. (WR 19).

Od początku ich relacji to Salomea, przyzwyczajona do wydawania szybkich decyzji, góruje nad sytuacją, ale też i rekonwalescencja bohatera nacechowana jest akcentami erotycznymi, przywołajmy scenę rozbierania i obmywania Odrowąża:

Powstaniec był prawie nagi, bo tylko w mokrych spodniach. Nie bez trudu ściągnęła go z sofki na prześcieradło rozpostarte w środku pokoju, głowę jego przechyliła poza obwód balii, do jej wnętrza, nad ciepłą wodę, i poczęła gąbką moczyć zaschłe sople, gruzły i zacieki w skrwawionych włosach. Wyżymała te włosy małymi rękoma z wybroczyn, dzieliła je na wąskie pasemka wydobywając troskliwie wciąż nowe zwitki wbite w rany od ciosów pałasza i bagnetu. Znalazłszy zaś ranę przemywała ją pieczołowicie, suszyła szarpią i starym płótnem. (WR 22).

Brynicka dokonuje oczyszczenia postaci z trudów wojennej zawieruchy w sposób „troskliwy” i „pieczołowity”. Odrowąż przestaje być wojownikiem, staje nagi i bezbronny wobec nowej sytuacji. To Salomea ${ }^{19}$ bierze na swoje barki jego ratunek oraz medyczną opiekę, nawet czynności wymagające skomplikowanego leczenia nie są jej obce, $w$ tych trudnych momentach bohaterka zachowuje swój cielesny urok: „Młoda lekarka długo w to oko świeciła latarnią i przy blasku łojówki badała sprawę. Prześliczne jej palce starały się znaleźć miejsce zranienia, namacać powiekę i gałkę oczną." (WR 22).

W czasie pielęgnacji czynność opatrywania mężczyzny staje się w powieści metaforą seksualnej inicjacji: „Najcięższa i najdrastyczniejsza rana była w biodrze. Młoda lekarka musiała zapomnieć o swym panieństwie i zupełnie

${ }_{18} \mathrm{Z}$ konfliktu między logosem i erosem wynika również symboliczny moment śmierci ojca, umierającego dokładnie w momencie utraty przez córkę dziewictwa: „Podwójnie, potrójnie, po tysiąckroć wielkie było jej cierpienie, gdy zestawiła daty i przekonała się, że ojciec dogasał w samotności wówczas, kiedy ona oddała się kochankowi. Umierał w tym czasie czy w pobliżu owej nocy niezapomnianej, kiedy ciężką i niewolę nakładającą wydawał jej się ojcowska miłość.” (WR 123). Więcej pisałem o tym w tekście: Świat osierocony. Ojcowie i córki w powieściach Stefana Żeromskiego z lat 1908-1919, [w]: Starość. Doświadczenie egzystencjalne - temat literacki - metafora kultury, red. A. Janicka, E. Wesołowska, G. Kowalski, Białystok 2013.

19 Por. B. Grodzki, Salomea Brynicka i „ciche bohaterki”, czyli o „Wiernej rzece” S. Żeromskiego - inaczej,[w]: Modernistyczny wizerunek człowieka. Studia historycznoliterackie, red. J. Szcześniak i D. Trześniowski, Lublin 2001. 
rannego obnażyć” (WR 23). Również oddanie panieńskiego łóżka ma znaczący charakter, Salomea ofiarowuje symbolicznie w ten sposób rannemu swoją niewinność i dziewictwo. W czasie gdy bohaterka sprząta, on podziwia jej sylwetkę, zapominając o trudach walki zbrojnej: „Szczęście zesłał mu Bóg po wielkim cierpieniu. Kiedy brnął przez lasy, wody i złorzeczył - czekało nań w tym domu. On sam, jeden, jedyny, został doń powołany[...]” (WR 23). W powieści następuje zamiana ról, kobieta - wojownik staje się obrończynią rannego żołnierza: „Zresztą na najgorszy moment mam tu jeszcze jednego obrońcę. - Gdzie? - A tu - oświadczyła z uśmiechem, wyciągając z kieszenie szerokiej sukni dwustrzałowy pistolet" (WR 31). Odczucia Salomei pełne są współczucia wobec bólu drugiego człowieka, ale i ona ma świadomość swojej urody: „Czując dobrze w spojrzeniu i w ruchach tego oficera wrażenie swej piękności, uczyniła się świadomie, z umysłu, stokroć piękniejszą i z całej mocy tego powabu pewnego siebie stworzyła sobie jakby puklerz obronny" (WR 54). Co istotne, to właśnie Brynicka inicjuje akt seksualny: „Całowała je łagodnie, delikatnie, jak kwiat, którego nie podobna napatrzeć się ani nawąchać - aż go wreszcie same usta przytulą do siebie. $Z$ zapomniałą miłością prowadziła wargami po pasmach jego włosów. Nie odwracał głowy przez czas długi, ani zdumiony, ani przejęty tym jej występkiem." (WR 111).

Podtytuł powieści, „klechda”, sugeruje odczytanie symboliczne ${ }^{20}$, widoczne już w chronologii „kalendarza pożądania” bohaterów; powrót do zdrowia Odrowąża odbywa się, jak w Dziejach grzechu, wiosną. Jednak wraz z upływem miesięcy w ich związku znika aspekt idealnie rozumianej miłości, intensyfikuje się aspekt cielesny, a Odrowąż coraz częściej dostrzega urodę Salomei: „Zęby, białe jak najczystszy obłok kwietniowy, uśmiechały się w pąsowych usteczkach" (WR 105). W postawie pielęgniarki zaczyna być obecne potęgujące się oddanie: „Lubiła, co lubił - nienawidziła, co mu sprawiało najlżejszą przykrość”. (WR 107), a tuż po ich stosunku erotycznym Salomea odczuwa ekstazę: „Uciec z tym człowiekiem! Zginąć gdzieś z nim w bitwie, w jakimś dzikim, zwierzęcym, iście moskiewskim zdarzeniu! Skonać z nim razem, tutaj lub gdzie indziej, byleby tylko samej w tym miejscu bez niego nie zostać". (WR 112). Od momentu inicjacji jej myślenie o świecie staje się optymistyczne ${ }^{21}$ : „Widziała obce miasta, słoneczne krainy[...] Widziała twarze ludzi, kształty gmachów, barwy pól , aleje i zagaja drzew w słonecznej, wyśnionej stronie. Tam to - daleko - odbywała się wędrówka z jej księciem panem..." (WR 115).

${ }^{20}$ Por. T. Linkner, W mitycznym nurcie „Wiernej rzeki”, „Ruch Literacki” 2000, z. 2.

${ }^{21}$ Uwagi te przeczą tym analizom miłości w twórczości Żeromskiego, które traktują Erosa wyłącznie jako siłę niszczącą: „Motywy nocy i ciemności w utworach Żeromskiego często łączą się z motywami miłosnymi. Eros jest dla pisarza wszechpotężną siłą, istniejąca poza wszelkimi systemami moralnymi, a więc wpisującą się w sferę mroku", cyt. z M.J. Olszewska, Bohaterowie Stefana Żeromskiego wobec nicości, [w]: tejże, Stefan Żeromski. Spotkania, Warszawa 2015, s. 144. 
Walcząc o życie i bezpieczeństwo kochanka Salomea wygrywa wielokrotnie, lecz jako kobieta zakochana przegrywa opuszczona. Jak zauważył Klaus Theweleit: „dla żołnierzy walczących w wojnie światowej poza pielęgniarkami nie istniały niemal żadne kobiety"22. Do mężczyzny należy w Wiernej rzece bój o niepodległość, kobieta zostaje w roli przydzielonej jej przez tradycje - może być wyłącznie pielęgniarką albo stać na straży domostwa.

\section{Zakończenie}

W opisywanych relacjach między pielęgniarkami a ich pacjentami w wybranych utworach Stefana Żeromskiego kobiety są obiektami miłości mężczyzn, którzy byli pod ich opieką. W Dziejach grzechu pobyt z chorym Łukaszem jest częścią wielu inicjacji Ewy, także tych erotycznych. W Promieniu choroba łączy śmiercią pielęgniarkę i ofiarę, w Wiernej rzece, pomimo fizycznej przewagi nad chorym, którą posiada Salomea Brynicka, bohaterka zostaje wykorzystana przez Odrowąża i pozostawiona swojemu losowi.

Zygmunt Pucko pisze o obecnym w mediach między drugą połową dziewiętnastego wieku a 1919 rokiem obrazem pielęgniarki określanej mianem „anioła miłosierdzia”. W modelu tym „najwyższą pozycję w hierarchii zajmuje miłosierna troska" ${ }^{23}$, W przypadku bohaterek prozy Żeromskiego postawa „anioła miłosierdzia" została jednak rozbudowana i łączy się z seksualną rolą opiekunki ${ }^{24}$.

W wymienionych utworach mamy także do czynienia ze swoistym odwróceniem losu, początkowo bowiem to mężczyźni są uzależnieni od swoich opiekunek, bez których nie mogą wrócić do zdrowia. Z czasem jednak angażują się w te relacje(czy wręcz je reżyserują) i przejmują nad nimi kontrole. Seksualny, erotyczny aspekt obcowania z pielęgniarką, zwłaszcza w Dziejach grzechu i Wiernej rzece, pojawia się w warunkach fizycznej niezdolności chorego, ale już wyleczenie oznacza koniec tej relacji oraz niweluje erotyczną grę zaistniałą w sytuacji opieki i oddania.

\section{Bibliografia załącznikowa}

Eile S., S. Kasztelowicz,Stefan Żeromski. Kalendarz życia i twórczości, Kraków 1976.

Eile S., ",Wierna rzeka” jako powieść historyczna, "Zeszyty Naukowe UJ” 1957, z. 3.

Głowiński M., Konstrukcja a recepcja (Wokół „Dziejów grzechu”), [w:] Tegoż, Gry powieściowe, Warszawa 1973.

${ }^{22}$ K. Theweleit, Męskie fantazje, przeł. M. Falkowski, M. Herer, Warszawa 2015, s. 134.

${ }^{23}$ Tamże, s. 8.

${ }^{24}$ Por. Z. Pucko: „utrzymywanie stosunków seksualnych pielęgniarki ze swymi podopiecznymi stanowi integralną część jej misji”, dz. cyt., s. 11. 
Gacki W., Kobiety i miłość w twórczości St. Żeromskiego, Warszawa 1936.

Gogolin A., Miłość w twórczości Stefana Żeromskiego, „Akant” 2006, nr 12.

Grodzki B., Salomea Brynicka i „ciche bohaterki", czyli o "Wiernej rzece”" S. Żeromskiego - inaczej, [w]: Modernistyczny wizerunek człowieka. Studia historycznoliterackie, red. J. Szcześniak i D. Trześniowski, Lublin 2001.

Grzymała-Siedlecki A., Dobra wieść o złym, „Tygodnik llustrowany” 1912, nr 19.

Gutowski W., Nagie dusze i maski. O młodopolskich mitach miłości, Kraków 1997.

Gutowski W., Stefan Żeromski - „Dzieje grzechu”, [w:] Lektury polonistyczne. Od realizmu do preekspresjonizmu, red. G. Matuszek, Kraków 2001.

Handke K., Handke R., Świat kobiet i świat mężczyzn. Słownictwo Pism Stefana Żeromskiego, t. XIII, Kraków 2007.

Handke K., Stosunek Stefana Żeromskiego do pejzaży: natury i miasta, w: Dworki-pejzaże - konie, red. K. Stępnik, Lublin 2002.

Hutnikiewicz A., Imiona miłości, [w:], Żeromski, Warszawa 2000, s. 278-302

Kochanowski M., Melodramatyzm i powieść (Żeromski, Mniszkówna, Strug). Od rytuału do sensacji, Białystok 2015.

Kochanowski M., Świat osierocony. Ojcowie i córki w powieściach Stefana Żeromskiego z lat 1908-1919, [w]: Starość. Doświadczenie egzystencjalne - temat literacki - metafora kultury, red. A. Janicka, E. Wesołowska, G. Kowalski, Białystok 2013.

Linkner T., W mitycznym nurcie "Wiernej rzeki”, „Ruch Literacki” 2000, z. 2.

Markiewicz H., Stefan Żeromski wobec rewolucji, „Pamiętnik Literacki” 1951, z. 1.

Młodopolski witalizm. Modernistyczne witalizmy, red. A. Czabanowska-Wróbel, U.M. Pilch, Kraków 2016.

Olszewska M.J., Stefana Żeromskiego dar widzenia i przenikania świata, [w]: tejże, Stefan Żeromski. Spotkania, Warszawa 2015.

Popiel M., „Dokąd płynie ta woda, dokąd płynie?”, „Ruch Literacki” 1980, nr 5.

Pucko Z., Wybrane motywy pielęgniarki w literaturze. Szkice filozoficzne, Kraków 2016.

Światy Stefana Żeromskiego, red. M.J. Olszewska, G.P. Bąbiak, Warszawa 2005.

Theweleit K., Męskie fantazje, przeł. M. Falkowski, M. Herer, Warszawa 2015.

Trześniowski D.,Kim jest Ewa Pobratyńska. Rzecz o antypsychologizmie Żeromskiego, [w:] Światy Stefana Żeromskiego: studia, red. M.J. Olszewska, G.P. Bąbiak, Warszawa 2005.

Turek W., O pierwszym wydaniu „Wiernej rzeki"Stefana Żeromskiego, „Pamiętnik Literacki” 2011, z. 1.

Wrońska A., Elementy paraboli w "Dziejach grzechu” Stefana Żeromskiego, „Kieleckie Studia Filologiczne" 1997, t. 11.

Zacharska J., Kobieta, wina igrzech w utworach Żeromskiego, [w:] Klucze do Żeromskiego, red. K. Stępnik, Lublin 2003.

Zalewska A., Legenda i lektura. O „Dziejach grzechu” Stefana Żeromskiego, Warszawa 2016.

Zdanowicz A., Metafizyka i życie społeczne. Stefan Żeromski wobec problemów współczesności, Warszawa 2005.

Zdanowicz A., W poszukiwaniu nowej „szkoły umierania” - o wczesnej twórczości Stefana Żeromskiego, w: Śmierć w literaturze i kulturze drugiej połowy XIX wieku, red. E. Paczoska, U. Kowalczuk, Warszawa 2002.

Żeromski S., Dzieje grzechu, edycja Pism Zebranych (t.12-13) pod red. Z. Golińskiego, Warszawa 2015.

Żeromski S., Promień, edycja Dzieł, pod red. S. Pigonia, t. 2, Warszawa 1955-1973.

Żeromski S., Wierna rzeka,edycja Dzieł, pod red. S. Pigonia, t. 10, Warszawa 1955-1973. 


\section{Streszczenie}

Artykuł przedstawia obraz pielęgniarki w wybranych utworach Stefana Żeromskiego oraz mężczyzn, którzy w momentach kryzysu stają się zależni od kobiety. W opisywanych relacjach kobiety są obiektami miłości mężczyzn, będących pod ich opieką. W Dziejach grzechu pobyt z chorym Łukaszem jest częścią wielu inicjacji Ewy. W Promieniu choroba łączy śmiercią pielęgniarkę i ofiarę, w Wiernej rzece bohaterka zostaje wykorzystana przez Odrowąża i pozostawiona. W analizowanych tekstach mamy do czynienia z odwróceniem losu, początkowo to mężczyźni są uzależnieni od swoich opiekunek. Z czasem angażują się w te relację (czy wręcz je reżyserują) i przejmują nad nią kontrole.

Słowa kluczowe: Pielęgniarka, ofiara, Żeromski, modernizm, powieść.

\section{Nurses in selected works by Stefan Żeromski}

\section{Summary}

The aim of this thesis is to analyze the image of a nurse and caregiver in selected works by Stefan Żeromski, as well as the image of men, dependent on women in the time of crisis. In relations analyzed here women are objects of love of men they care. In Dzieje grzechu staying with Lukasz in his illnessis the source of initiation for Ewa. In Promien the sickness and deathlinks the nurse with the victim, in Wierna rzeka Odrowąż lefts his care giver alone after beinghealed. In the analyzed texts we are dealing with the reversal of the fate, initially the men are addicted to their caregivers, then they engage in this relationship (or even direct it) and take control over it.

Keywords: Nurse, victim, Zeromski, modernism, novel. 